\title{
Ecological aspects of modern city-planning
}

\author{
Angela Mottaeva ${ }^{1,2,{ }^{*}, \text { Natalya Kalinina }}{ }^{3}$, Anna Kuzmina $^{4}$, Olga Olenina $^{5}$ and Aznaur \\ Glashev $^{1}$
}

\author{
${ }^{1}$ Moscow State University of Civil Engineering, 26, Yaroslavskoye Shosse, 129337, Moscow, Russia \\ ${ }^{2}$ Moscow Region State University, Radio str, 10A, 105005, Moscow, Russia \\ ${ }^{3}$ Friendship University of Russia, Ordzhonikidze str., 3, 115419, Moscow, Russia \\ ${ }^{4}$ Saint Petersburg State University, Universitetskaya Embankment,7-9, 199034, St. Petersburg, Russia \\ ${ }^{5}$ Russian university of Transport, Obrztsov St., 9, 127994, Moscow, Russia
}

\begin{abstract}
Directions for creation of a steady eco-city (or an eco-district) and the criteria of stability and environmental friendliness of the cities are presented. The authors also recognize that the sustainable eco-friendly development of the city demands association of the matters of the so called "green" agenda and the "brown" agenda. On the other hand, there are places where the sharp social inequality and the interfaced social problems are presented. The authors prove that, although the economic activity of cities leads to serious environmental problems, cities have the greatest potential for developing ways of sustainable environmental development.
\end{abstract}

\section{Introduction}

The effect on the environment, delivered by modern cities, tend to be maximum. Reduction of spatial resources; reconsolidation; excessive intensification; pollution; existence of ownerless, degrading, extreme, pathogenic spaces, hazardous to humans' health; their sharp differentiation, connected with social processes, make the matter of the increase in spatial and ecological qualities of the cities relevant. The nature and even humans begin to be forced out from the cities by the equipment, communications, machinery, structures. The share of environmentally friendly space decreases.

Spatial environmental problems are sharply shown at the welfare level as well. It is the partial loss of traditional spatial culture by the population, which is connected with the reduction of ethnic spaces, insufficient attention to spatial interaction of the person and the social environment during design works, dissatisfaction with the level of the esthetic organization of the environment [1].

These problems result in the need to consider some ecological aspects during city planning and city construction. The special attention is required for the large industrial cities, which are in difficult ecological conditions [2].

The issues of the city environment have actively raised in the research works since the 1970ths (at first when studying environmental protection, then within town-planning ecology and landscape ecological works, during the development of design of the architectural environment). We should mention the works by A.P. Vergunov, V.V.

\footnotetext{
* Corresponding author: angela-1309.m@yandex.ru
} 
Vladimirov, N.M. Dyomin, A.G. Bolshakov, V.A. Kolyasnikov, Ya.V. Kositsky, N.S. Krasnoshchyokova, I.V. Lazareva, B.M. Poluy, G.Yu. Smykovskaya, A.N. Tetior, S.B. Chistyakova, Z.N. Yargina, O.N. Yanitsky, C. Alexander, K. Doksiadis, E.M. Mikulin's works, V.A. Nefyodov, L.V. Anisimova, I.A. Fomin, O. Genisaretsky, M. Konik, D. Saymonds, A.V. Yefimova, V.T. Shimko, T.A. Gavrilina. Social-and-culturological environmental problems are considered by V.L. Glazychev, Ch. Jenks, V.K. Paderin, L.B. Kogan, A.G. Rappaport, V.A. Sitarov, E.Yu. Smotritsky, D.O. Shvidkovsky's works, P. Nessa, P. Raberg, R. Piyetil, T. Toyama, K. Moore, R. Steiner. Environmental issues of design, as well as the architectural-and-spatial organization of the inhabited, production and public environment are reflected in works by V.V. Aleksashina, B.M. Davidson, S.A. Dekterev, A.V. Krasheninnikov, A.D. Kulikov, V.K. Litskevich, V.S. Fedosikhin, A.Yu. Feropontov, S.G. Shabiyev's.

\section{Materials and Methods}

During the city planning and city construction, essentially new steady eco-city or ecodistrict with the maximum use of some eco-compatible decisions, allowing minimizing or completely excluding the pollution environment, can be recommended. That will help to increase the quality of life, to bring the inhabitant closer to the nature, to improve understanding of support of the environment, to reduce energy consumption, etc. (Table 1).

Table 1. Direction of creation of a steady eco-city.

\begin{tabular}{|l|c|c|c|c|}
\hline $\begin{array}{l}\text { Improvement } \\
\text { of the } \\
\text { developed } \\
\text { places of } \\
\text { resettlement }\end{array}$ & $\begin{array}{c}\text { Ecoreconstruction } \\
\text { of the city and } \\
\text { buildings. Visio- } \\
\text { ecology. The } \\
\text { displacement of } \\
\text { some facilities } \\
\text { under the earth. } \\
\text { Energy saving, the } \\
\text { use of renewable } \\
\text { energy sources }\end{array}$ & $\begin{array}{c}\text { Ecological } \\
\text { zoning, } \\
\text { favorable } \\
\text { placement of } \\
\text { the industry. } \\
\text { Greening of } \\
\text { transport }\end{array}$ & $\begin{array}{c}\text { Phytomelioration. } \\
\text { Gardening of } \\
\text { very vertical and } \\
\text { horizontal surface }\end{array}$ & $\begin{array}{c}\text { Deep sewage } \\
\text { treatment and } \\
\text { system of } \\
\text { collecting waste. } \\
\text { Collecting and } \\
\text { the use of rain } \\
\text { water. }\end{array}$ \\
\hline $\begin{array}{l}\text { Development } \\
\text { of new eco- } \\
\text { friendly } \\
\text { decisions for } \\
\text { places of } \\
\text { resettlement, } \\
\text { buildings and } \\
\text { structures }\end{array}$ & $\begin{array}{c}\text { Achievement of } \\
\text { ecological } \\
\text { equilibrium, } \\
\text { miniaturization of } \\
\text { places of } \\
\text { resettlement }\end{array}$ & $\begin{array}{c}\text { Solution of } \\
\text { problems of } \\
\text { sensory } \\
\text { ccology (sight, } \\
\text { smell, sound) }\end{array}$ & $\begin{array}{c}\text { Deep cleaning of } \\
\text { pollution, system } \\
\text { of utilization and } \\
\text { reuse }\end{array}$ & $\begin{array}{c}\text { Completely } \\
\text { steady } \\
\text { biopositive place } \\
\text { of resettlement } \\
\text { (eco-city) }\end{array}$ \\
\hline $\begin{array}{l}\text { Essentially } \\
\text { new decisions } \\
\text { for eco- } \\
\text { friendly places } \\
\text { of } \\
\text { resettlement }\end{array}$ & $\begin{array}{c}\text { Achievement of } \\
\text { ecological } \\
\text { equilibrium on the } \\
\text { Earth }\end{array}$ & $\begin{array}{c}\text { Biopositive } \\
\text { places of } \\
\text { resettlement on } \\
\text { the shelf }\end{array}$ & $\begin{array}{c}\text { Biopositive } \\
\text { places of } \\
\text { resettlement on } \\
\text { the Moon and in } \\
\text { the space }\end{array}$ & $\begin{array}{c}\text { Biopositive } \\
\text { places of } \\
\text { resettlement on } \\
\text { other planets }\end{array}$ \\
\hline
\end{tabular}

The degree of stability and environmental friendliness of the city can be estimated with several criteria $[3,4]$ :

- whether the city minimizes global influences (minimization of the use of energy and resources, exception of waste and pollution); 
- whether the city minimizes regional influences (pollution of water basins, rivers, air, soil, etc.);

- whether the city provides the existence of diverse and extensive natural territories for animals and plants;

- whether the city gives to each person ample opportunities and a wide choice for realization of his or her needs;

- whether the city is adapted for convenient, pleasant, quiet, healthy, steady life of each inhabitant;

- whether the city provides the opportunity for constant communication of inhabitants;

- whether the city provides equal opportunities for various ethnic, age, cultural, professional and other groups;

- whether the city is the self-regulating structure, developing as a complex system and reacting to changes with straight lines and feedback;

- whether the city interrupts natural streams of substances and energy;

- whether the city provides the existence of sufficient vital space for each inhabitant (whether the population density is rather small);

- whether all life forms and human activities in the city are rather eco-friendly (transport, industry, power, etc.);

- whether all the decisions of buildings and engineering structures are eco-friendly (biopositive);

- whether the soil and vegetable layer remains in the built-up territories;

- - whether the city provides ecological education of inhabitants and formation of new eco-friendly ethics by new urbanistic-and-ecological and architectural-and-construction decisions.

Steady eco-city is created, on the one hand, for inhabitants (improvement of life quality, approach to the nature, energy economy, encouragement of movement by bicycle or on foot, etc.), and, on the other hand, for support of the nature [5, 6]. It is possible to point out the purposes of the eco-city creation (Table 2).

Table 2. Purposes of creation of eco-city.

\begin{tabular}{|l|l|}
\hline \multicolumn{1}{|c|}{ For inhabitants: } & \multicolumn{1}{c|}{ For the nature: } \\
\hline $\begin{array}{l}\text { 1. Improvement of quality of life (cleaner air, } \\
\text { greens, low building, clear water, eco-friendly } \\
\text { materials, etc.). }\end{array}$ & $\begin{array}{l}\text { 1. Restoration, healing of the biosphere (air, } \\
\text { water, soil, biodiversity, ecocommunications), } \\
\text { replenishment of energy, biomass, food. }\end{array}$ \\
\hline $\begin{array}{l}\text { 2. Continuous ecological education of adult } \\
\text { inhabitants and children, approach to the nature. }\end{array}$ & $\begin{array}{l}\text { 2. Gardening, creation of green channels for } \\
\text { free migration of animals. }\end{array}$ \\
\hline $\begin{array}{l}\text { 3. Encouragement of communes, } \\
\text { communication of inhabitants in the communes } \\
\text { (everything for the maximum communication is } \\
\text { provided in eco-cities). }\end{array}$ & $\begin{array}{l}\text { 3. Reduction or exception of pollution of the } \\
\text { nature from the city. }\end{array}$ \\
\hline $\begin{array}{l}\text { 4. Ensuring health and safety of inhabitants. } \\
\text { d. The use of renewable energy and reduction } \\
\text { of consumption of not renewable energy, not } \\
\text { renewable materials. }\end{array}$ \\
\hline $\begin{array}{l}\text { 5. Ensuring public justice (there is no sharp } \\
\text { difference in sizes and quality of housing). }\end{array}$ & $\begin{array}{l}\text { 5. Reduction of the square of the city, } \\
\text { prevention of "spread" of the cities, } \\
\text { preservation of natural landscapes from } \\
\text { buildings. }\end{array}$ \\
\hline $\begin{array}{l}\text { 6. Encouragement of small producers and } \\
\text { dealers (the 1st floor of the building is supposed } \\
\text { for workshops or shops, cafes, the 2nd floor is }\end{array}$ & $\begin{array}{l}\text { 6. Reduction of pollution and destruction of } \\
\text { the nature from transport. }\end{array}$ \\
\hline
\end{tabular}




\begin{tabular}{|l|l|}
\hline an the apartment). & \\
\hline $\begin{array}{l}\text { 7. Energy saving, profitability of housing in } \\
\text { general. Promotion of natural technologies. }\end{array}$ & $\begin{array}{l}\text { 7. Gradual change in the positive direction of } \\
\text { the relation of people to the nature. }\end{array}$ \\
\hline 8. Respect for historical heritage. & $\begin{array}{l}\text { 8. Preservation of the nature. Maintenance of } \\
\text { sites of the "wild" nature. }\end{array}$ \\
\hline $\begin{array}{l}\text { 9. Increase in esthetic qualities of the city. } \\
\text { Perception of the city as the natural component } \\
\text { of the environment, its inclusion in the } \\
\text { ecosystem. }\end{array}$ & $\begin{array}{l}\text { 9. As the result: maintenance of ecological } \\
\text { equilibrium between the developed and natural } \\
\text { territories. }\end{array}$ \\
\hline
\end{tabular}

\section{Results}

Having studied the international experience it is possible to reveal the following ecological priorities:

- Development of the regional system of open spaces (agricultural, forest, natural and planted trees and shrubs territories), which role increases during climatic changes. It is planned that the urbanized spaces will make $90 \%$ in agglomeration, open spaces will make only $10 \%$ of the territory; the share of open spaces will be $60 \%$ in the "Green belt", while urbanized spaces will occupy $40 \%$; open spaces will prevail $(90 \%)$ in the territory of the "Agricultural crown" and only $10 \%$ will be supposed to develop as the urbanized territories.

- Preservation and development of continuity of the ecological framework (including valleys of the small and big rivers, water corridors).

- Steady management of ecosystems and natural resources.

- That provides the rational use of water resources (ensuring specific water consumption no more than 215 liters a day per a person); improvement of quality of water; providing the biodiversity due to the creation of "buffer" zones; protection of soils and the use of underground space; ensuring quality of atmospheric air and decrease in physical and chemical influences; creation of "green lungs" and "tranquility zones"; control of consumption of energy resources and reduction of power vulnerability; use of alternative energy sources.

- Reduction of territorial disproportions according to the requirements of environmental protection (ensuring availability of the planted trees and shrubs spaces and "silence zones", reduction of air pollution and risk management of natural and technogenic character (prevention of floods, creation of "buffer zones" from pollution sources, decrease in pollution of soils and reduction of sanitary risks).

- Preservation, creation and management of landscapes and cultural heritage for the increase in appeal, the identity of quality of life in the region $[7,8,9,10]$.

Irrespectively Asian, American or European cities are engaged in territorial planning, the priority task is the greatest possible preservation of the nature during the spatial development of the city and the quality maintenance of the environment during the implementation of city-planning projects.

\section{Discussion}

Performing the activities for ensuring sustainable development of the cities planners, as well as other specialists in the issues of city development and political authorities, face a serious practical dilemma: how to unite two groups of matters of the "green" agenda and the "brown" agenda, i.e. the problem of the natural environment and the habitat of the person $[11,12,13,14]$. 
Sustainable development of the city demands association of the matters of the "green" agenda and the "brown" agenda (Table 3).

Table 3. Contents of the green and brown agenda.

\begin{tabular}{|l|l|}
\hline \multicolumn{1}{|c|}{ Green agenda } & \multicolumn{1}{|c|}{ Brown agenda } \\
\hline $\begin{array}{l}\text { Natural ecosystems (global, regional and } \\
\text { local), used by the cities as the sources of } \\
\text { ensuring services. }\end{array}$ & $\begin{array}{l}\text { Systems of dwelling for humans, necessary for } \\
\text { creation of the urban environment, which will be } \\
\text { favourable, healthy and suitable for life. }\end{array}$ \\
\hline $\begin{array}{l}\text { The ecosystems providing environmentally } \\
\text { friendly open space, used by the city for the } \\
\text { conservation of biodiversity and for the } \\
\text { creation of conditions for the inhabitants' } \\
\text { recreation. }\end{array}$ & $\begin{array}{l}\text { The systems of waste disposal, processing and } \\
\text { export of waste from the cities, including solid } \\
\text { and liquid waste, the system of the treatment } \\
\text { facilities reducing negative impact of harmful } \\
\text { emissions and drains on components of the city } \\
\text { landscape. }\end{array}$ \\
\hline $\begin{array}{l}\text { The water management systems, used by the } \\
\text { cities as the natural source of water supply } \\
\text { and the place of acceptance of drains. }\end{array}$ & $\begin{array}{l}\text { The power supply systems, providing the city } \\
\text { services with energy, heat conditioned by air and } \\
\text { light. }\end{array}$ \\
\hline $\begin{array}{l}\text { The climatic and air resources, providing } \\
\text { necessary favorable conditions for } \\
\text { comfortable stay of the population in the } \\
\text { cities. }\end{array}$ & $\begin{array}{l}\text { The transport systems, providing movement in } \\
\text { the cities. }\end{array}$ \\
\hline $\begin{array}{l}\text { Other types of service, connected with natural } \\
\text { resources, including the agricultural and } \\
\text { forestry and landscape systems, providing the } \\
\text { cities with food and wood. }\end{array}$ & $\begin{array}{l}\text { The construction systems and building materials } \\
\text { providing the material basis of life in the cities. }\end{array}$ \\
\hline
\end{tabular}

\section{Conclusions}

Creation of ecologically favorable conditions in the cities is not a simple process. It demands the careful analysis of the initial state to formulate the problems and the action plan for their decision. The cities, where nearly a half of the population of the planet lives, are the concentrators of achievements of mankind. On the other hand they are places, where social inequality sharply and the interfaced social problems are presented. Concentration of the industry and municipal infrastructure lead to serious environmental problems. The cities have big inertness in relation to nature protection innovations. Nevertheless the cities have the largest potential for the development of ways for sustainable development.

The main task of the authorities of all the levels is to create conditions, when people will construct the cities with the use of new, ecologically effective technologies, considering local traditions and native-and--climatic conditions, to make city-planning decisions taking into account some ecological principles. It will allow implementation of the difficult and long-term ecologically focused reconstruction of the cities.

\section{References}

1. T.H. Tietenberg, Environmental economics and policy (HarperCollins College Publishers, New York, 1994)

2. E. Chibisova, Journal of International Scientific Publications: Economy \& Business 5(2), 600 (2015)

3. K. Kunanbayeva, A. Gorovoy, A. Butyrin, MATEC Web of Conferences 193, 05048 (2018)

4. E. Vasilyeva, MATEC Web of Conference 193, 01025 (2018) 
5. E. Vasilyeva, IOP Conference Series Earth and Environmental Science 90(1), 012216 (2017)

6. D. Radushinsky, A. Mottaeva, L. Andreeva, G. Dyakova, IOP Conf. Series: Earth and Environmental Science 90, 012137 (2017) doi :10.1088/1755-1315/90/1/012218

7. As. Mottaeva, MATEC Web of Conferences 170, 01045 (2018) doi.org/10.1051/matecconf/201817001045

8. I. Markina, A. Sharkova, Journal of Applied Economic Sciences 9(4), 687-693 (2014)

9. E. Ganebnykh, A. Mottaeva, T. Larinina, E. Petrova, MATEC Web of Conferences 170, 01044 (2018) doi.org/10.1051/matecconf/201817001044

10. I. Markina, A. Sharkova, M. Barna, International Journal of Entrepreneurship 22(3), 13-25 (2018)

11. I.V. Ivashkina, Matters of regional ecology 1, 26-31 (2010)

12. A.E. Gutnov, I.G. Lezhava, Future of the city (Stroyizdant, Moscow, 2007)

13. V. Blinov, Science and life 3, 30 (2009)

14. A.V. Gorodkov, Higher education institutions news. Construction 5, 98 (2000) 